\title{
SADA AASTAT EMAKEELE SELTSI: TEE JA TÄHISED
}

\author{
JÜRI VALGE
}

\begin{abstract}
Annotatsioon. Artiklis vaadeldakse Emakeele Seltsi arengut ja tegevust selle asutamisest 23. märtsil 1920 kuni tänapäevani. Kirjeldatakse seltsi nime muutmist ja suhteid Tartu ülikooli ja teaduste akadeemiaga. Vaatluse alla võetakse seltsi liikmeskond ja selle kujunemist mõjutanud põhikirjamuudatused. Analüüsitakse seltsi tuntust ja mõju, võrreldakse 100 aastat tagasi püstitatud põhikirjalisi eesmärke tänapäevastega ning kirjeldatakse saavutusi nende täitmisel seltsi peamistes tegevusvaldkondades: murdekogumisel, keelearenduses, nimede eestistamisel, keelelises mainekujunduses ja keelepoliitikas.
\end{abstract}

Võtmesõnad: Emakeele Selts, eesti keel

Enam-vähem kõikidel oma saja-aastase olemasolu aegadel on Emakeele Selts olnud Eesti keele-, teadus- ja kultuurielus, sh kogu rahvuslikus eneseteadvustamisprotsessis, nähtav ning neid ka mõjutanud, eri aegadel küll erinevate võimalustega ja eri aspekte rõhutades ning erineva edukusega. Emakeele Seltsi tegevusperioode on käsitlenud Heino Ahven (1955, 1970), Arnold Kask (1930, 1940) ja Mati Erelt (2010); ilmunud on ka seltsi lühikroonika (Valge 2020). Järgnevalt üritagem võrrelda selle sajandipikkuse teekonna algust ja lõppu ning kirjeldagem üldjoontes vahepeal tehtut, aga ka sunnitud pause ja põiklemisi.

Kokkuvõttest alustades võib öelda, et asutamisaegne selts mahub oma ettevõtmistega praegu eksisteeriva sisse: tollal kokku lepitu ja eesmärgiks seatu on ühel või teisel kujul kas saavutatud või alles, üht-teist aga on juurde tulnud, sest nii eesti keel kui ka selle kasutusruumi tagav ühiskond ja riik on läbi elanud muutusi. 


\section{Seltsi nimi}

Seltsi esimene ametlik nimi oli Emakeele Selts, kuigi juba esimeses, ülikooli ajutises nõukogus 19. mail 1920 kinnitatud põhikirjas viitas kõik sellele, et mõeldi akadeemilist ühendust: kinnitati ülikooli juurde kuulumist, peamiste liikmetena käsitleti ,akadeemia kodanikke“ ning esimehekski pidi olema „keegi ülikooli õppejõududest“. Kui juhatus laskis esimese põhikirja ära trükkida, oligi ,akadeemiline“ sinna lisatud. Ametlikuks muutus täpsustatud nimi siis, kui algul üldkoosolek ja seejärel 29. aprillil 1925 ka Tartu-Võru Rahukogu seltsi nimele „Akadeemilise“ ette pani (Pk-II).

1950ndate algul jäid nii selts kui ka tema nimi tollastele EKP keskkomitee VIII pleenumi (1950) vaimus tegutsevatele võimudele jalgu. Kui ENSV Teaduste Akadeemia (TA) presiidiumis 31. märtsil 1951 tehtud seltsi likvideerimise otsus õnnestus silmapaistvalt aktiivse ja oludele vastava tegutsemisega tõrjuda (19. detsembril 1951 tühistas presiidium oma märtsikuise otsuse), siis nimemuudatus tuli vaid teadmiseks võtta: seltsilt küsimata võttis Ministrite Nõukogu oma 13. septembri 1952. aasta otsusega nr 43 ,Akadeemilise“ seltsi nimest lihtsalt ära ja tõi ühenduse oma arust niimoodi massidele lähemale. Seltsile teatas toimunust akadeemia kaadriosakonna ülem I. Kuzminõh, tehes ühtlasi korralduse vahetada ära vanad pitsatid ja stambid (TA 1952). Tõsi, juba varem oli akadeemiaski seltsi juhatusele märku antud, et „kodanluseaegne nimi““ hästi ei sobi.

Nimeprobleem kerkis taas esile siis, kui 1980ndate lõpul riigi taasiseseisvumise tuules hakkas sõltumatuks arenema ka selts. Uue, 30. märtsil 1989 vastu võetud põhikirja ( $\mathrm{Pk}-\mathrm{X})$ koostamisel oli seltsi taas akadeemiliseks nimetamine üpris tugevalt päevakorral, aga sellest loobuti. Mööndes nimemuudatusega kaasnenud võimalikku prestiižikadu ja ajalooliste seoste nõrgenemist, tuleb tunnistada, et uus nimi võimaldas seltsi lihtsamalt vastu võtta paljusid teenekaid, aga akadeemilise hariduseta murdekorrespondente ja teisi keeleprofessionaalide ringist väljaspool olijaid ning sobib seltsi hilisema laienenud tegevusega. 


\section{Suhe ülikooliga}

Asutatud Tartu Ülikooli juurde, on (A)ES olnud ülikooliga seotud tegelikult kogu oma olemasolu aja. Kuni 1925. aastani tuli TÜ-le igal aastal esitada ka liikmete nimestik ning aruanne ,tegevusest ja varanduste seisust" (Pk-I). Hiljem seda kohustust enam polnud, kuid sidemed ülikooliga tagasid nii kontori- ja koosolekuruumide saamise ülikoolilt, võimaluse deponeerida oma kogud selle allasutustesse (eesti keele ja sugukeelte arhiivi / eesti keele arhiivi) kui ka ülikooli korralised rahalised toetused (nende tagamiseks jätkas selts ka oma tegevuse kohta info esitamist ülikoolile). Sellist sidet soodustavaks teguriks, selle aluseks on jätkuvalt olnud paljude seltsi liikmete, eelkõige selle juhtide seos Tartu Ülikooliga.

Tihedaim oli seltsi seos ülikooliga II maailmasõja ning sellele eelnenud ja järgnenud aastail, ulatudes kuni täieliku sõltuvuseni rektoraadi otsustest. Juba Nõukogude perioodil 1940-41 võeti AESi töövõtulepingulise staatusega töötajad lepingulistena tööle ülikooli. Saksa ajal, mil seltsi tegevus oli juriidiliselt peatatud, oli seltsi peaaegu ainus rahastusallikas ülikool ning võimalikku säilinud tegevust juhtis valimisjärgse, aga taanduma sunnitud esimehe Andrus Saareste asemel rektor Edgar Kanti poolt seltsi hooldajaks määratud põhikirjajärgne abiesimees Johannes Voldemar Veski. Ka hinnaliste murdekogude evakueerimine (= päästmine) toimus koos ülikooli teiste kultuurivarade päästmisega ning ülikooli ja seltsi ühiskorraldusel toodi need ka Tartusse tagasi, kus need jõudsid 1945. aasta kevadeks peahoone keldri kaudu linnalt ülikoolile ja ülikoolilt seltsile kasutada antud ruumidesse aadressil Mäe 33. (Order 1944)

Negatiivseks tahuks muidu asjalikus ja võimalustele vastavas koostöös on ülikooli otsus mitte tunnistada seltsi 7. märtsil 1944. aastal rektori kinnitatud põhikirjas (Pk-V) juriidilise isikuna. Ei rahalise toetuse tagamiseks ega koosolekuloa saamiseks polnud seltsil muud võimalust kui sellele kategoorilisele nõudmisele vastu tulla. Tegelikkuses ei muutunud seeläbi küll midagi - nagu ka mitte seetõttu, et see staatus poolteist aastat hiljem nõukogulikus ülikoolis kinnitatud põhikirjaga tagasi saadi. 


\section{Suhe teaduste akadeemiaga}

Eesti Teaduste Akadeemia (ETA) asutati 28. jaanuaril 1938. Kuna selts 1930ndate lõpul akadeemiaga ei ühinenud, siis polegi nende toonase suhte kohta peale suure konflikti ja selle lahendamise katsete kirjeldamise palju öelda. Tõenäoliselt on see ka periood - või perioodi algus -, mil mõnede seltsiliikmete krussis suhted kõige enam seltsi tegevust on mõjutanud (tundub, et teiste asjaosaliste rolli lõpuni kirjeldamata on Mihkel Toomsele veidi liiga tehtud). Konflikt oli tekitatud juba ETA asutamisel plaaniga, mille järgi taheti tuua kõik teadusseltsid vast asutatud akadeemia alluvusse, et tõsta selle mainet. Vastuolu põhisisuks oli küsimus, kas selts on 1925. aasta põhikirjale vastavalt juriidiline isik ning oma varade peremees või kaotab ta selle staatuse ja koos sellega ka varad, k.a hinnalised murdekogud.

See, et enamiku sõjaeelsest lühikesest ajast sisustas AESi ja akadeemia suhteid konflikt, ei ole siiski absoluutne. Mingil määral otsiti kompromissi mõlemal pool. Et ,tulevikus Vabariigi Valitsusel ja Eesti Teaduste Akadeemial eri aladel tehtava teadusliku töö paremat reguleerimist võimaldada“, kinnitas selts 19. märtsi 1939. aasta erakorralisel peakoosolekul, et on ,iseseisva teadusliku asutisena ja juriidilise isikuna valmis astuma Eesti Teaduste Akadeemiaga lähedasse koostöösse eesti ja sugukeelte uurimise alal, esitades Akadeemiale igal aastal oma tegevuse aruanded, eelarved ja kavad, eeldusega, et vastastikused informatsioonid ja nõupidamised sel ühisel tööalal teevad võimalikuks senisest veel suuremate tulemuste saavutamise" (Niilus 1940: 50). Akadeemiagi ei ajanud alati ainult oma joont, vaid aitas vähemalt seltsi 1938. aasta murdekogumistoetuse bürokraatlike takistuste tagant välja (Schlossmann 1939a). Muidugi tuleb silmas pidada, et akadeemial oli kohustus ellu viia riiklikku poliitikat, mis ei pruukinud seltsile kõige sobivam olla ning millele selts püüdis oma väheste võimaluste piires vastuväiteid esitada: ,--- Ak. Emakeele Selts ei näi arvestavat soowe Seltsi uurimistöö ümberkorraldamise alal“ (Schlossmann 1939b).

Teist korda tuli akadeemia AESi ellu 1946. aastal, siis juba ENSV TAna. Sõjajärgne akadeemia jättis seltsile juriidilise isiku staatuse küll Nõukogude perioodi lõpuni alles, kuid tegelikkuses oli see üks paljudest süsteemi silmakirjalikkuse väljendustest. Iseseisvust seltsil ei olnud. Tõsi, ega akadeemia isegi mingi sõltumatu organisatsioon olnud, vaid väga piiratud omaotsustusega NSV Liidu teadus- ja muu poliitika elluviimise instrument. 
Seos TAga on säilinud ka pärast Eesti iseseisvumist, aga 4. veebruaril 1998. aastal sõlmitud assotsiatsioonilepingu kohaselt seisneb see vaid sisulises partnerluses, infovahetuses ja teineteise toetuses ning akadeemia rahalises dotatsioonis. Sisuliselt on selts tagasi jõudnud 1925. aasta põhikirjaga kehtestatud olukorrani (n-ö emaorganisatsiooniks on ülikooli asemel akadeemia): ta on juriidilise isikuna iseseisev ja oma otsustes sõltumatu.

Nõukogude aja suhe akadeemiaga algas seltsi jaoks 31. mail 1946, mil see allutati TAle ning varad (sh murdekogud) võeti ülikoolilt ja seltsilt üle: „--- Eesti NSV Teaduste Akadeemia on võtnud vastu kõik Akadeemilisele Emakeele Seltsile kuuluvad õigused ja vara inventariraamatutes loetletud koosseisus vara asukohas Tartus, Mäe tn. nr.33“ (TA 1946).

Kirjeldades suhteid 1940ndate ja 1950ndate ning kohati ka hilisemate aegade akadeemiaga, tuleb möönda, et see alluvussuhe tõi seltsile küll kaasa mitmeid ebameeldivusi, mis oleksid ilmselt aset leidnud ka TAta, ent samas pakkus ka võimalusi, mida vahest muidu poleks olnud. Tõenäoliselt olid - ka personaalsetest suhetest tulenevalt - pehmemad keskvõimude võimalikud löögid. Piisaval määral või mitte, aga tõsiasi on see, et ESi rahastati pikka aega valdavas osas akadeemia kaudu, liikmemaksud moodustasid (ja moodustavad) kulude katmiseks vajalikust vaid väikese osa ning nendegi kättesaamisel on olnud ergutav ja oluline TA roll. TA kaudu toimus kirjastamisprotsess ning vähene välissuhtluski oleks ilma akadeemia vahenduseta tõenäoliselt olnud veel piiratum või lausa mõeldamatu. Sõjajärgse ja hilisemagi suure ruumipuuduse kontekstis on kindlasti põhjust hinnata ruume, mille kasutamist akadeemia seltsile võimaldas.

Sellel, et akadeemia paiknes Tallinnas ning sinna viidi ka Keele ja Kirjanduse Instituut koos sellele seltsilt üle võetud murdekogudega, oli AESi tegevusele esialgu kahtlemata negatiivne mõju: kogud hajutati, uurimisvõimalused Tartus ahenesid, keskasutuse kontroll ning mõju läksid vahetumaks ja suuremaks, seltsile järjekordsest koha kättenäitamise löögist rääkimata. Halva mängu juures, kus TA asepresident G. Naan kordas oma 25. septembri 1953. aasta kirjas nõuet ka seltsi asjaajamine „k.a. oktoobrikuu jooksul Tartust Tallinna“ tuua (Naan 1953), on tunnustust vääriv juhatuse esimehe Veski kategooriline vastus: „Seni, kuni Emakeele Seltsi ruumide küsimus Tallinnas ei ole rahuldavalt lahendatud, ei pea Seltsi juhatus otstarbekohaseks ega soovitavaks Seltsi asjaajamise üleviimist Tallinna ja teeb Teile ettepaneku jätta Seltsi asjaajamine seniks 
Tartu“(Veski 1953). Lõpptulemusele vaatamata tuleb nentida, et Tallinnas paiknevate kogudega pandi alus teise tugeva murdeuurimiskeskuse tekkele Eestis, lisaks laiendas asjaajamise ning ettekande- ja hiljem aastakoosolekutegi korraldamine ka Tallinnas seltsi seni valdavalt Tartu-keskset tegevussfääri.

\section{Liikmeskond}

Suure osa tegevuste ja asjaajamise viimine Tallinna mõjutas loomulikult seltsi liikmeskonna kujunemist, luues eeldused ESi tänini kestvaks laienemiseks nii liikmete arvu kui ka päritolu(koha) mõttes. Seltsi esimesest asutamiskoosolekust osavõtjaid registreeriti 14, 23. aprillil 1920 teisel asutamiskoosolekul põhikirjale alla kirjutanuid on 41, kellest 17 on märgitud asutajaliikmeiks (nende hulgas professorid Lauri Kettunen, Matthias Johann Eisen ja Max Vasmer, aga samuti August Annist, Oskar Loorits, Julius Mägiste, Ernst Nurm, Ants Oras, Andrus Saareste). Teiste allkirjastajate hulgast leiame veel kaks professorit (Hans Oldekopi ja Hugo Bernhard Rahamäe ${ }^{1}$ ) ning Villem Ernitsa, Mihkel Kampmaa, Paulopriit Voolaine, Johannes Voldemar Veski, Gustav Vilbaste jt (AESA 1920: 3); ülikooli nõukogule adresseeritud põhikirja kinnitamise palvele on alla kirjutanud ka 23. märtsi koosolekust osa võtnud Jaan Jõgever. Enamik neist oli Tartu Ülikooliga seotud. Ka seltsi vastuvõtmisel, samuti nagu aruandluseski tehti vahet ülikooli- ja mitte-ülikooliinimeste vahel, hilisemas valimisprotseduuris ka Tartu ja mitte-Tartu päritolu liikmete vahel.

Tänapäevased vastuvõtutingimused on ühesugused kõigi jaoks ning aastaaruannetes on kirjas elukoht. Ka sellise liikmeskonnastatistikaga nagu 1950ndail (vt Ahven 1959: 316) enam ei tegelda. 31. detsembril 2019 kuulus ESi 379 tegevliiget (Mei 2020: 328). Suur hulk seltsiliikmeid on praegugi TÜst või selle lõpetanute hulgast, ent nendega liituvad ka Tallinna Ülikooli vilistlased ja Eesti Keele Instituudi mõlema kõrgkooli lõpetanutest töötajad. Seltsi on tuldud ka muudest ametiasutustest. Geograafiliselt on enim liikmeid Tallinnast (170), järgneb Tartu (133); kui saared välja arvata, siis pole ühtki maakonda, kus ES esindatud poleks.

Jõudsalt on 1980ndate 1õpust alates kasvanud ESi välisliikmete arv. Sisuliselt olid välisliikmed juba seltsi asutaja Lauri Kettunen ise ning teinegi asutajaliige, Peterburist Tartu kaudu (töötas TÜs 1919-21)

\footnotetext{
1 Teistel andmetel dotsent.
} 
Leipzigi siirdunud slavist professor Max Vasmer; hiljem lisandus teisigi, nt 1937. aastal võeti vastu Lauri Posti (Soome) ja Jenö Fazekas (Ungari). 1940.-1989. aastani pääseti seltsi ainult „,raudse eesriide“ idapoolelt. Seltsiga liitus soome-ugri hõimurahvaste esindajaid, esmajoones Paul Ariste õpilasi, nt Lidia Vassikova (Joškar-Ola), Ivan Tarakanov (Iževsk), Maria Zaitseva (Petroskoi), Ivan Galkin (Joškar-Ola), Üzbäk Baitšura (Kaasan), samuti NSV Liitu, k.a Tartusse õppima saabunud ungarlasi: Sándor Mokány (Leningrad), Imre Zékány (Užgorod). Lätist tulid Hilda Grīva ja Silvia Rage jt. Välisliikmete tõeline juurdevool algas koos taasiseseisvumise käigus vastu võetud uue põhikirjaga 30. märtsil 1989. Esimesed olid Kalevi Wiik Turust ja Raimo Raag Uppsalast. Järgnesid Mauno Koski, Kari Laukkanen, Matti Punttila, Harri Mürk, Ilse Lehiste jt.

Lauri Kettunenil oli au olla ka AESi esimene auliige (valiti 01.02.1925) ja sõja eel said selle tiitli veel 11 teenekat keelemeest Eestist (Oskar Kallas, Johannes Voldemar Veski ja Johannes Aavik), Soomest, Norrast ja Ungarist; küllap seltsi heaolu silmas pidades valiti auliikmeks ka Päts ja Laidoner (1939). Pärast sõja ja võimuvahetustega seotud pausi sai 1948. aastal auliikmeks Leningradi akadeemik Dmitri Bubrich - küll teenitult, aga temagi täiesti selge tagamõttega. Seejärel läks veel 18 aastat järgmise auliikme, Friedebert Tuglase valimiseni (1966). Kokku oli selts Kettunenist alates kuni oma juubelini valinud 54 auliiget, neist väljastpoolt Eestit pärast sõda ainult ühe - komi Vassili Lõtkini. 1960ndate lõpu ja 1970ndate alguse üritus valida seltsile au-, aga ka teisi liikmeid läänest ebaõnnestus EKP keskkomitee vastuseisu tõttu. 23. märtsiks 2020 kavandatud juubelikoosolekul oli kavas Eevi Rossi kõrval valida kaks auliiget ka Soomest: Auli Hakulinen ja Hannu Remes. Paraku sundis Covid-19 pandeemia koosolekut edasi lükkama ning valimine sai teoks alles 27. augustil.

Auliikmete võimalus tegevliikmete kõrval on olnud olemas kõikide põhikirjade järgi, v.a päris esimene ja 1941. aastal jõustamata jäänud põhikirjaprojekt. Nii on see ka praegu. Seltsile rahalise toetuse hankimiseks otsustas aga juhatus juba asutamisaastal luua toetajaliikme institutsiooni (üldkoosolek kiitis vastava põhikirjamuudatuse heaks 06.02.1921). Nõukogude võimule see termin ega sellega seostuv tegevus ei sobinud, kuigi 1947. aasta põhikirjas olid toetajad liikmed Saksa-aegse põhikirja inertsist tulenevalt veel alles; võimalik, et see nimetus sobis 1944. aasta põhikirja 
kirjutatud lihtliikmest veidi pareminigi ning lisaks võisid määratluse „tunnevad huvi, aitavad kaasa“ alla mahtuda ka võimalikud annetajad. Lihtliikmeid ei võetud seltsi vastu kunagi.

Juba 1941. aastal oli toetajaliikme asemele sisse toodud asjaosalise haridustaset mittetähtsustav kirjavahetajaliikme staatus ning see võeti kasutusele ka 1953. ja 1961. aastal. Viimasel juhul mahtusid selle mõiste alla ka seltsi ainelised toetajad. Vahetult pärast Stalini surma vastu võetud 1953. aasta põhikiri meenutas aga 1941. aasta projekti, milles ainelisest toetusest polnud sõnagi: 1953. aasta põhikirja järgi oli kirjavahetajaliikme ülesanne kaasa aidata „keelelise materjali kogumisel“. Muu hulgas avas see tee seltsi ka erialase hariduseta murdekorrespondentidele. 1989. aastast alates, kui nii sisus kui ka vormis üritati liikuda tagasi esimese iseseisvuse aegse, 1925/33. aasta põhikirja poole, võeti toetajaliikme staatus tavapärasest suurema liikmemaksu või annetusega seltsi toetaja tähenduses taas kasutusele, laiendades seda ka juriidilistele isikutele. Alates 1999. aastast toetajaliikme terminit enam ei kasutata ning seltsi saab toetada liikmestaatust vastu saamata.

ESi aastaraamatu numbrites 35-42 toodud seltsi liikmete nimestikus on 30 ESi liikme kohta kasutatud terminit „,välisliige“, mida ükski põhikiri pole ette näinud. Lihtsalt informatiivsel eesmärgil on seltsi väljaspool Eestit elavaid liikmeid eraldi nimekirjadena esitatud hiljemgi.

\section{Tuntuse ja mõju kasvatamine}

Geograafilise haarde laienemine ei ole loomulikult seotud mitte ainult seltsi liikmete elu- ja töökohaga, vaid ka sellega, kus selts oma tööd teeb, st üritusi korraldas/korraldab. Siin on erinevus 1920ndate ja praeguse aja vahel väga suur. Ainult Tartus peetavate ettekandekoosolekutega ei piirdunud tegevus muidugi ka 1920. ja 1930. aastail. Osaleti vaimse kultuuri päevadel ja raamatuaasta üritustel, nimede eestistamisel ja keelenõu jagamisel, ka üle riigi ulatuvate toetuskampaaniate korraldamisel - rääkimata murdekogumisest, mille käigus saadeti stipendiaate kümnetesse kihelkondadesse. Loomulikult mõjutas selts Eesti keeleelu ka kaudselt, suunates ja survestades nii haridusministeeriumi (ja kogu haridussüsteemi), ajalehe- jm toimetusi (ja kogu lugejaskonda), postivalitsust kui ka kindralstaapi kasutama seltsi põhimõtete järgset kirjakeelt. AESi kirjavahetus oli aukartustäratav. 
Tänapäeval ja veelgi olulisemalt 1960.-1980. aastatel laienes ESi tuntus ja mõju üle maa keelepäevade kaudu. Vaevalt oskas regulaarselt ESi tööd arutanud ja ettepanekuid teinud TA presiidium ette kujutada, missuguse ulatuse ja vormi omandab ühingu ,Teadus“ juhtidega 4. novembri 1959. aasta ühisistungil otsustatu elluviimine: ,Teha ülesandeks Akadeemia teaduslikele seltsidele ning Ühingu sektsioonidele arendada koostööd teadmiste levitamise alal, eriti tugevdada seda tööd maal ja väikestes keskustes“ (TAP 1959). Pisut enam kui aasta pärast, 15. veebruaril 1961 kordas akadeemia presiidium otsuse veelgi konkreetsemas vormis üle, sidudes selle täitmise seltsi vastutava sekretäriga (JProt 525), ning laupäeval, 8. aprillil 1961 otsustas ESi juhatus: , Korraldada Viljandis septembrikuu teisel poolel keelepäev“ (JProt 528). Koostöös Viljandi rajooni haridusja kultuuriosakonnaga korraldatigi 7. oktoobril 1961 Viljandis esimene keelepäev, mis pani aluse tänini kestvale traditsioonile.

Keelepäevade koguarvu on tänapäeval raskem öelda kui nende korraldamise algusaastatel (vt Tender 2000), sest selle nimega on hakatud tähistama mitmesuguseid, paljude korraldajate poolt eesti keelele pühendatud üritusi. Tõsiasi on, et nende hulk küünib sadadeni ja osavõtjate arv paljude tuhandeteni. Keelepäevade korraldamine viis okupatsiooni lõpukümnenditel seltsi Eesti paljudesse kohtadesse, kujutades muu hulgas varjatud vastupanu üha tugevnevale venestussurvele. Keelepäevade kahtlusteta õnnestunud sarjast ei ole võimalik rääkida nimetamata Heino Ahvenat, kes oli kuni surmani nende korraldamise hing ning võttis seda tööd lausa isikliku missioonina (vt Tender, Viikberg 2020).

Emakeelekeskse rahvusliku eneseteadvuse toetamisele on suunatud ka ESi tänapäevane, sh Tallinna- ja Tartu-väline tegevus. Loomulikult aitavad sellele suuresti kaasa raadio ja televisioon ning internet, mis seltsi kodulehe www.emakeeleselts.ee kaudu ja juhatusel pakuvad võimaluse seltsi tegevusest osa saada tegelikult igale soovijale. Kasvanud tehnilistele võimalustele vaatamata on otseste kontaktide tähtsus säilinud või kohati kasvanudki; selles mõttes on väga olulised ESi Eesti äärealade keelepäevad, mis on toimunud Kihnus, Ruhnus, Muhus, Vormsis, Pranglil, Narvas ja Missos. 12. märtsil 1989 korraldati koos Läti Eesti Seltsiga Riias esimene keelepäev väljaspool Eestit, pärast 12-aastast vaheaega teine Peterburis (vt Hussar 2010) ning sellest alates on nende korraldamine muutunud pidevaks, hõlmates Euroopale lisaks teisi kontinente (Ameerika, Austraalia), kus eestlasi elab. 


\section{Tegevusvormide kujunemine ja mitmekesistumine}

Geograafilise laienemise kõrval on seltsi tegevus jagunenud ka sisuliselt, kuid tänapäeval vormiliselt ilmselt mõnevõrra vähem kui algusaastakümneil. Seltsi esimeses põhikirjas pole toimkondadest juttu (küll juba 1925. aasta omas), ent sisuliselt algas nende moodustamine kohe - nimede eestistamise ja murdekogumisega, hiljem ka ühenduses stenograafiaga ja Eesti Keele väljaandmisega (selle toimetus oli toimkonna staatuses seltsi osa). Lisaks oli hulgaliselt mingi konkreetse probleemi lahendamiseks moodustatud ja lühikest aega toiminud komisjone, k.a 1939. aastal moodustatud keelekomisjon.

Tänapäeva ESis tegutseb esimest korda 1963. aastal loodud keeletoimkond: asutatud, suletud ja siis jälle moodustatud. Pärast Vabariigi Valitsuse 2006. aasta määrust nr 196 kannab see ka eesti kirjakeele normi tagamise riiklikku funktsiooni (VV 2006). Ka sõjajärgne murdetoimkond moodustati 1963. aastal ja tegutses muu hulgas murdekogumisvõistlusi korraldades aktiivselt 1990ndate keskpaigani, mille järel tegevus aegamööda hääbus. Aastas kaks korda planeerimiseks kogunev ja artiklikäsikirju arutav Oma Keele toimetuskolleegium on oma ülesandega hakkama saanud, kuid kunagise Eesti Keele toimetuse pideva tegutsemisega pole selle tegevus võrreldav. Pikemat või lühemat aega toimivad ja toimetaja vaeva vähem või rohkem kergendavad toimetuskolleegiumid on / on olnud ka teistel ESi väljaannetel, eelkõige muidugi seltsi aastaraamatutel.

Aktiivselt tegutseb ka poolformaalne noortesektsioon - mõningaid paralleele võib tõmmata kunagise üliõpilaste keeleringiga (asutatud 1945) - ja vahepealsest ajast tuleb kindlasti nimetada aastail 1966-95 tegutsenud ESi rahvaluulesektsiooni ning 1977. aastal asutatud ja 1980ndate keskpaigast alates aeglaselt hääbunud lingvistilise poeetika ja stilistika sektsiooni. Nende sektsioonide puhul on oluline see, et ESi kattevarjus sai võimalikuks 1940. aastal suletud Akadeemilise Rahvaluule Seltsi ja Eesti Kirjanduse Seltsi sisuline elluäratamine ja tööleasumine. Kui tekkis võimalus need taastada, kadus ka vajadus ESi kõnealuste sektsioonide järele.

Väiksema haarde ja konkreetse tähtajalise ülesandega töörühmadest võib nimetada mitmeid sõnaraamatu-, terminoloogia-, kohanime- jm komisjone 1920. ja 1930. aastatest; hiina ja kreeka nimede, konverentside ja võistluste korraldamise, keeleseaduse eelnõu analüüsi jm komisjone viimastest aastakümnetest. Tundub, et viimasel ajal on komisjonidele 
koos nende kodukordade ja muude bürokraatlike protseduuridega vähem tähelepanu pööratud: lihtsalt lepitakse kokku ja tehakse vajalikud asjad ära.

ESi on ikka iseloomustanud osavõtt teiste, ka riiklike või üleriigiliste töörühmade tegevusest. Juba päris alguses, 1920. aastal saadeti oma esindajad Ants Oras ja Oskar Loorits Eesti Kirjanduse Seltsi „õigekirjutuse sõnaraamatu väljaandmise komisjoni““(AESA 1920: 11), töötati äsja asutatud Eesti Kultuurkapitali kirjanduse sihtkapitali valitsuses ja Fenno-Ugrias, 1930ndate lõpul ka Rahvuskultuuri ja Rahvahariduse Nõukogus. Praegune ES on esindatud rohkete keelega tegelevate ühenduste juhtorganites: Eesti keelenõukogus, teadus- ja uurimisasutuste ning kõrgkoolide nõukogudes, auhinnakomisjonides, riiklike programmide juhtkomiteedes jm.

Rohkesti näiteid on seltsi osaluse kohta suurte üleriigiliste ürituste, nt raamatuaasta (1935) ja eestikeelse piibli juubeliaasta korraldamisel (1939) ning loomulikult oma toimkonnaga nimede eestistamisel peaaegu kogu esimese iseseisvusaja jooksul. Viimase aja ettevõtmistest kuuluvad silmapaistvamate hulka osavõtt keeleseaduse väljatöötamisest, seejuures öeldi keeleseaduse idee esimest korda avalikult välja just ESi koosolekul (1988), ja kõikide eesti keele arengukavade koostamisest (sisuliselt alates 1999. aastast), eesti keele aasta ürituste korraldamine terve 2019. aasta jooksul. Kuni viimase ajani on leidnud kõrgel tasemel järgimist (ELi esinduse poolt, presidendi algatatuna) ja saanud ka seltsi tuge ESi keeletoimkonnas sündinud idee korraldada sõnaloomevõistlus „Kes leiab sobiva sõna?“ (1972) ning populaarsust on kogumas seltsi (kaas)korraldatavad kokkuvõttevõistlus „Tuum“ ja eestikeelsete ettevõttenimede võistlus „Ehe Eesti - Eesti ettevõttele eesti nimi“،, emakeelepäeva etteütlusest rääkimata. Mainitagu sedagi, et ühendus ei ole kõhelnud tegemast ka poliitilisi otsuseid, kui seda eesti keele eest seismisel vaja on olnud (1980. ja 1990. aastate vahetusel).

Olukordi, kus seltsi aktiivne eesti keelt soosiv tegevus ei olnud täiesti riskivaba, tuli muidugi ette okupatsioonide ajal: Saksa võimudele polnud meelt mööda ei seltsi katsed oma tegevusele ka ametlikke raame saada (Kiri 567-K) ega Andrus Saareste ja Hella Keema pühendumus. Nõukogude ajalgi teenis selts akadeemia presiidiumi 13. juuni 1952. aasta koosolekul süüdistuse nõukogudevastasuses, kuna seltsi juhatus ,ei taha tunnistada valitsuse määrusi ega suhtu neisse nõukogulikult" (JProt 399), kui üritas - tõsi, tulutult - vastu seista murdekogude hajutamisele ning 
seltsi enda keskuse viimisele akadeemilisest Tartust võimukesksesse ja kontrollialusesse Tallinna.

Riiklikule ja peavoolule vastu seismist on tulnud loomulikult rohkem ette rahulikumatel aegadel. 1920ndatel protesteeriti vene keele liigkasutamise vastu ülikoolis ning eesti keele tundide vähesuse üle seminaride õpetajakoolituses, avaldati survet nimede eestistamise kiirendamiseks. Kui vaidlusi paljude kohanimede üle võib pidada normaalse tööprotsessi osaks, siis vastasseis pealinna nimega seoses oli põhimõttelist laadi. Võimalik, et kohati jäid AESi seisukohad nendes klaarimistes liigagi domineerivalt peale (nagu näiteks sõnaraamatukeele levitamises), kohati aga oldi sunnitud tõdema, et võimu vastu ei saa: pealinnaks tuli Tallinn seltsi soovitatud nimekuju Tallinna asemel; ei läinud käiku ka eet rahaühikuna ega riigivanem, mille asemele tuli president. Tagantjärele targana võib küll tõdeda, et vahest keerati vint kohati üle. Sõjajärgsetest vastasseisudest nimetagem eesti keele uue tähestiku ning võõrpärisnimede häälduspärase kirjutamise ettepanekute tõrjumist; hiljem võitlemist Katariina kolledži ning lauluvõistluste liigse inglise ja vähese eesti keele kasutamise vastu. Siingi on läinud kord nii, kord jälle teisiti.

\section{Põhikirjaliste eesmärkide püstitamine ja elluviimine}

Ideaalide ja tehtu võrdlemist sobib alustada seltsi esimeses ning praegu kehtivas põhikirjas kirjapandut kõrvutades. 1920: „Emakeele Seltsil --on ülesandeks äratada huvi eesti keele tundmise, arendamise ja uurimise vastu, selles mõttes ka kirjandust, rahvaluulet, rahvateadust ja sugulaskeeli silmas pidades“(AESA 1920: 1-2). 2011: „Emakeele Seltsi eesmärgid on: a) kaasa aidata eesti keele, sugulaskeelte ja etnoloogia teaduslikule uurimisele; b) kaasa aidata eesti keele kasutamisele riigikeelena ning ülemaalise suhtluskeelena; c) äratada avalikku huvi eesti keele ja sugulaskeelte vastu; d) edendada filoloogide akadeemilist suhtlemist ja ühisüritusi, samuti nende koostööd eesti keele huvilistega" (Pk-XIII).

Kui 1920. aastal seati eesmärgiks ,äratada huvi“, siis tänapäevane põhikiri kutsub kolmes alapunktis neljast „kaasa aitama“ ja neljas langeb sisuliselt kokku 100 aastat tagasi sätestatuga. On arusaadav, et keele arendamist sellisel kujul, nagu oli sajand tagasi eesmärgiks seatud, ei ole tänapäeval vaja: keeletoimkonna töö on siiski vaid peenhäälestus. Kindlasti on tänapäevases põhikirjas suurem roll eesti keele kasutusel. 1920. aastal 
ei mainita kasutamist üldse, 1925. aastal on laiemad ringkonnad, kelles tuleb ,eesti keele ühiskondliku seisundi vastu“ huvi äratada, küll märgitud, aga praeguse põhikirja eesmärgist „,kaasa aidata eesti keele kasutamisele riigikeelena ning ülemaalise suhtluskeelena“ jäävad need kaugele. Mainigem, et 1989. aasta eesmärk, kui kasutamist oli täpsustatud laiendiga „takistamatu“, oli veelgi ajakohasem ja võitluslikum. Vahepealsetel aastakümnetel oleks sellise täpsustuse kasutamine olnud kas olulisel määral tarbetu või siis okupatsioonide ajal võimatu.

Sajand tagasi polnud kirja pandud filoloogide ja teiste keelehuviliste (akadeemilise) suhtluse edendamist. Ettekande- ja peakoosolekute asjalikust ja mõnikord konfliktsestki õhkkonnast erineva stiiliga tee- ja auõhtuid korraldas AES ka enne sõda (seltsi aastapäevad, teenekate liikmete tähtpäevad), ent nende tähtsus ja tähendus ei saanudki ulatuda hilisemate, sõjajärgsete kohtumiste tasemele, kui vajadus seltsikaaslase siira toetuse järele oli varasemast suurem. Loomulikult arutati võõra võimu aegsetel seltsiliikmete koosolemistel ka otseseid, poliitiliselt neutraalseid keeleasju. Samas räägiti ka paljust muust, mille kuulamiseks AESis/ESis oli soovimatuid kõrvu küllap keskmisest vähem. Iseloomulik on, et kõnealune eesmärk - edendada suhtlust - jõudis põhikirja siis, kui suu kinni hoidmiseks enam vägivallaaastatega võrreldavat põhjust ei olnud. Suurem hulk vabadust oli mõningaid endisi võimalusi kärpinud ja uusi piire tekitanud.

Loomulikult on seltsiliikmete vahel ja seltsis tervikuna olnud vastuolusid, aga need jäävad usalduse, empaatia, abistamissoovi ja teiste eesti keelt ning kaasseltsilisi ja partnereid väärtustavate omaduste varju. Majanduslikult rasketel aegadel aidati Setu lauluemasid ning osteti liivi ja lutsi lastele raamatuid, värvipliiatseid ja jõulupuid; hiljem on toetatud seltsi auliikmeid. Seltsilt saadi abi nimede eestistamise sageli delikaatsete ja raskete otsuste tegemisel; selts tõttas üpris suuri riske võttes aitama oma hätta sattunud korrespondenti Aadu Toomessalu (1956) ning toetas kohati uskumatu järjekindlusega Armin Kukke ja Valter Niilust mobilisatsioonist pääsemisel ning Andrus Saarestet sõnaraamatutöös (1944).

Hinnates kõrgelt aegade jooksul ESi kuulunud ja sellega koostööd teinud inimeste panust ja pühendumust, tuleb siiski eriliselt tunnustada seltsi rasketest aegadest läbi tüürinud juhtide, eelkõige Johannes Voldemar Veski, Arnod Kase, Paul Ariste ja Heino Ahvena teeneid. Selts on olnud oma juhtide nägu. Juhatuseliikmete koosolekul 11. veebruaril 1945 tõdeti, et: „ei jäetaks kasutamata ühtki võimalust, et seda tööd, mida AES 
seni on teinud, jätkata ja edasi viia“ (JProt 329). Mõlema okupatsiooni kõige keerulisematel aegadel seda ka tehti - ja tulemuslikult. Selts mitte ainult ei jäänud alles, vaid ka tegutses. Nii nagu eesti keelel, ei ole ESilgi päris lihtsaid aegu olnud. Seepärast väärivad kindlasti tunnustamist seltsi pikaaegsemad esimehed (juba nimetatute kõrval) Huno Rätsep, Mati Erelt ja Helle Metslang. Toetava ja hoolitsevalt pehme vormi andis enam kui poole sajandi jooksul ESi tegevusele Helju Kaal.

Lühikeste põhikirjatekstide enam-vähem ühesuguste ja üldiste eesmärkide alla mahub mitmeid konkreetseid tegevusi. Saja aasta taha ulatuvalt jätkub tänapäevalgi ettekandekoosolekute korraldamine. Selle kõrvale on tulnud 1968. aastast alates J. V. Veski päev, Eesti keeleinimeste prestiižsseim foorum (Kingisepp 1989; Valge 2018), ning üpris tugevasti on kinnistunud vaheldumisi Tartus ja Tallinnas toimuvate ESi üliõpilaskonverentside tava. Aastakümnetetagused harvad rahvusvahelise suhtluse võimalused kahvatuvad tänapäevase konverentsikülluse ees.

Ulatusliku ja aktiivse nimede eestistamise lõpetas küll Nõukogude võim, kuid teisalt - suur osa võõrapärase nime omanikest, ligi 210000 , oligi juba oma perekonnanimele eestipärase kuju leidnud. Lõpusirgele, kuigi mitte päris lõppu, jõudis 1940ndate alguseks süstemaatiline murdekogumine; tõeline lõpetamine algusaastate kriteeriumide järgi läks suuremalt jaolt Keele ja Kirjanduse Instituudi hoolde. Ei jäänud sellest aga seltski kõrvale, tehes koostööd nii instituudi kui kõrgkoolidega, korraldades kogujate koolitust ja kogumisvõistlusi ning organiseerides üleliidulistki koostööd. Veel 1992 algatas ES (koostöös TÜga) Eesti Rahvuskultuuri Fondi toetusel Vastseliinale ja Kihnule keskenduva mitmeaastase projekti „Eesti murdeainese süvendav kogumine“ - ning sai sada aastat pärast Paulopriit Voolaine minekut lutside juurde jälle oma stipendiaadid.

\section{Seltsi väljaanded}

Saavutus, mille esimesi vilju saadi nautida juba ESi teisel tegutsemisaastal, on seltsi väljaanded. Kui tähtsaks publitseerimistegevust peeti, osutab selle kirjutamine põhikirja. Üllatavalt kiiresti publitseerimiskohustuse täitmisega läkski: toimetised hakkasid ilmuma juba 1921. aastal ja samal aastal ilmus ka esimene aastaraamat. Pärast arusaadavat katkestust on neist - koos vahepealse 48. vihiku kaotamise ja leidmisega ning juba enne sõda alanud numeratsioonisegadusega - jõudnud tänapäevani seltsi 
toimetiste sari. Ka enne sõda olid lausa klassikaks saanud mitmed väljaanded, nagu Elmar Muugi raamatud „Eesti keeleõpetus I. Hääliku- ja vormiõpetus“ ja „Lühike eesti keeleõpetus I“ (mõlemad 1927, vastavalt AESi toimetised 12 ja 13), Valter Tauli ,Õigekeelsuse ja keelekorralduse põhimõtted ja meetodid“ (1938, nr 17), Andrus Saareste ja A. R. Cederbergi „Valik eesti kirjakeele vanemaid mälestisi“ (1930, nr 16), Julius Mägiste toimetatud „Soome-eesti sõnaraamat“ (1931, nr 19), aga üldiselt oli ikkagi tegemist õhukeste vihikukestega. Eraldi tuleb muidugi mainida liivi lugemikke, millest sai toimetiste sari alguse, ning nimede raamatuid. Kui toimetiste väljaandmine 1958. aastal taas jätkus, olid esimesed „Johannes Voldemar Veski keelelisi töid“ ja Arnold Kase „Võitlus vana ja uue kirjaviisi vahel XIX sajandi eesti kirjakeeles“. Nimetatagu veel Juhan Peegli „Nimisõna poeetilised sünonüümid eesti regivärssides“ (1982-1991, nr 15), Toomas Pauli „Eesti piiblitõlke ajalugu“(1999, nr 72), seitsmesse väljaandesse ulatuvat Paul Ariste vadja tsüklit, Huno Rätsepa „Eesti keele lihtlausete tüüpe“ (1978, nr 12) ja mitmeid teisi. Käsitletava perioodi lõpuks on ilmunud kokku 78 toimetiste väljaannet, viimastena Asta ja Katre Õimu „Lähtekohti eesti fraseoloogia käsitlemiseks“ (2019, nr 76), Heli Laanekase „Eesti filoloog olla“ (2020, nr 77) ja Reet Kasiku „Elav ja muutuv keel“ (2021, nr 78). Autori ja toimetajate väga pika töö tulemusena ilmus seltsi väljaandel Gustav Vilbaste „Eesti taimenimetusi“ (1993, nr 20).

Seltsi aastaraamat taastati 1955 , kuid juba selle esimene number meenutas vähe esimest viit, aastail 1921-26 ilmunud aastakokkuvõtet, mille põhiosa moodustasidki aruanded, põhikirjad ja kodukorrad ning liikmete ja komisjonide nimestikud. Eelretsenseeritava ja rahvusvaheliselt tunnustatuna pakub tänapäevane ESA avaldamisvõimalust ja lugemisrõõmu nii seltsi liikmeile kui ka väljaspool seltsi. Sõjaeelsest aastaraamatute traditsioonist on üle võetud aastaaruannete, liikmenimekirjade jm kroonikat puudutava avaldamine. Aastaraamatute hulgas väärib esile tõstmist „Eesti keele arendamise strateegia 2004-2010“ koostamistööde käigus valminud number 48, mis 255 leheküljel võtab kokku eesti keele uurimise analüüsi.

Ajakiri Eesti Keel, mis nägi ilmavalgust 1922, oli viimane seltsi kolmest asutamisperioodi väljaandest, mida hakati välja andma. Avanumbri saatesõnades määratakse kindlaks ajakirja tegevuskava: „Emakeele Seltsi ajakirjana on Eesti Keele ülesanne sama kui Emakeele Seltsil, s. o. eesti 
keele kõigekülgne uurimine. --- Puhtteaduslik olles ei või Eesti Keel ka tegelikust eesti keele tarvitamisest ja selle korraldamisest täitsa vaikides mööda minna, eraldi mis puutub eesti keele õpperaamatutesse. --- Keele ühtlust, täpipealsust ja korrapärasust püütakse ajakirjas eriti rõhutada“ (Toimetus 1922).

Ka sõja järel taastatud väljaannete hulgas oli ajakiri viimane. Kui valdavalt populaarteadusliku Oma Keele esimene number 2000. aasta hilissügisel ilmus, oli Eesti Keele seismajäämisest 1941. aastal (1940. aasta viimase, (kaksik)numbriga) kulunud 60 aastat. Tõsi, vahepeal olid olnud nii Kodumurre kui ka ilmumist jätkav aastaraamat, mis võtsid keeleajakirja rolli vähemalt sisuliselt enda kanda. Tõsi on ka see, et Eesti Keelt Oma Keelega eriti võrrelda ei saa. Viimase eesmärgid ja sihtrühm, aga ka tase on teised: „Oma Keel on esimene kõigile keelehuvilistele mõeldud ajakiri Eestis. --- Kirjutiste valikul ja ainestiku esitusviisil peame eriti oluliseks, et kõik see oleks huvitav, vajalik ja jõukohane gümnaasiumiõpilastele“" (Erelt 2000: 5).

Nimetatud kolme väljaande - toimetiste, aastaraamatu, ajakirja kõrval väärivad kindlasti mainimist kogumikeks koondatud ESi murdekorrespondentide tekstivalimikud. Eesti Keele veergudel avaldatud üksiktekstide järel on alates 1956. aastast ilmunud üheksa valimikku. Tähtsustamaks üht ESi ajaloolist peaülesannet ja -tegevust, murdekogumist, olgu need kõik siin ära toodud: „Valimik korrespondentide murdetekste I“(1956), ,Pajatusi põhjarannikult" (1957), ,Tuulik, kadakas ja leib“ (kogunud Aadu Toomessalu; 1969), „Lahemaa lugusid“ (koostanud Mari Must; 1989), „Tartumaa saja-aastaste jutud“ (kogunud Hella Keem; 1995), „Kuiss vanal Võromaal eleti““(2005), „Ennemuistitsel Mulgimaal““(2008), „Minevikupärandit Häädemeestelt“ (kogunud Marta Mäesalu; 2012), „Loode-Eesti murdelood. Risti ja Harju-Madise“ (Evi Juhkam; 2017).

\section{Sugulaskeelte uurimise toetamine}

Üks tegevusvaldkond, millesse ESi juhtide isiklikulgi algatusel seltsi esimestel aastatel lausa sukelduti, oli ,sugukeelte silmaspidamine“. Alustati lähemate, liivi, ingeri ja vadjaga. Kõiki kolme toetati materiaalselt, emakeelekõnelejatel võimaldati Eestisse, eelkõige Tartusse õppima tulla. Soodustati ka õppurite tegevust oma emakeelte talletamiseks: Arnold Kask kirjutab AESi tegevusülevaates, et „tuleb märkida A. Angere ingeri 
keele sõnakogu ja Dm. Tsvetkovi² poolt koostatud vadja sõnastikku“ “ (Kask 1940: 43). Liivlane, kelle kaudu ja kelle keeletöö toetuseks seltsi abi sageli liikus, oli Karl Stalte. Nõukogudeaegsed esimesed põhikirjad hõimurahvaste keeltega tegelemist ette ei näinud, kuid seltsiliikmete, eelkõige Paul Ariste, Eduard Vääri, Tiit-Rein Viitso, Mati Hindi jt algatusel ja osalusel see töö jätkus - kõrgkoolide ning Keele ja Kirjanduse Instituudi kaudu. Silmapaistvateks saavutusteks hõimukeeltega seoses on Paul Ariste ideede levik idapoolsete soomeugrilaste (komide, maride, udmurtide, ersade, mokšade, karjalaste) juurde tema aspirantide kaudu ning seeläbi nende rahvuslike fennougristikakoolkondade toetamine.

\section{Lõpetuseks}

ESi teekonnal on alanud teine aastasada. Lauri Kettuneni kutse 23. märtsil 1920 vastu võtnud tosinkonna ,akadeemilise kodaniku“ üritusest on saanud elujõuline, mitmesaja liikme ning kindla tulevikuvaatega ühendus.

Saja aasta jooksul on seltsi liikmed kogunud murdekeelt ja aidanud eestistada nimesid, osalenud keelearenduses ja keelelises mainetegevuses. Kõike seda on ka kirja pandud ning niiviisi meie keeleväärtusi talletatud tehtud kättesaadavaks nii tänapäeva kui ka tuleviku huvilistele. Oluline koht seltsi tegevuses on olnud ettekandekoosolekutel, mis on levitanud teadmisi emakeelest ja pakkunud võimalust kõrgetasemeliseks filoloogiliseks suhtluseks. Nagu põhikirjaski öeldud, pole unustatud sugulaskeeli ega naabervaldkondi.

Kõikidel aladel, millega selts on tegelnud, on saavutusi, mis sageli on eeldanud ennastületavaid pingutusi. Nii töörohketel massilise murdekogumise aastatel kui hiljemgi on ESi pühendunud liikmetele pisikesest või olematust töötasust olulisem olnud võimalus järgida oma sisetunde kutset. Riigikeele ja ülemaalise suhtluskeele rolliga emakeelt tuleb hoida ja harida, eriti kui mänguväljaks on üleilmastumine ning partneriteks inglise keel, arvuti ja eestlastest oluliselt suuremad rahvad, kes kõik oma emakeeli kasutavad. Keskmisest madalama keelelise valuläve ja vahest suurema vastutustundega inimesed ja neid ühendav selts on vajalikud, et selles kõrges mängus tulemuslikult kaasa mängida.

2 Tsvetkov koostas ka käsikirjalise vadja keele grammatika, mis ilmus Jüri Viikbergi toimetatuna 2008. aastal. 
Eelkirjeldatud vajadusest koorub nähtavale veel üks ESi iseloomustav omadus: kui keele ja ühiskonna areng on seltsi mõnest selle ülesandest ilma jätnud, st koos seltsiga selle lahendanud, on ikka esile kerkinud mingi uus keeleline probleem, mille lahendamiseks on ESi ühinenud keeleinimeste abi vajatud. Sajandi jooksul saavutatud tuntus ja omandatud maine lubavad seltsil seda abi ka pakkuda. Säilitanud oma akadeemilisuse, on Emakeele Selts samal ajal arenenud kogu rahva seltsiks olemise poole.

\section{Kirjandus}

AESA 1920 = Liikmete nimestik. - Akadeemilise Emakeele Seltsi aastaraamat. I. 1920. Tartu, 1921, 3.

Ahven, Heino 1955. Emakeele Seltsi tegevusest sõjajärgseil aastail (19451954). - Emakeele Seltsi aastaraamat I (1955). Tallinn: Eesti Riiklik Kirjastus, 5-26.

Ahven, Heino 1959. Aruanne Emakeele Seltsi tööst aastal 1957. - Emakeele Seltsi aastaraamat IV (1958). Tallinn: Eesti Riiklik Kirjastus, 312-317.

Ahven, Heino 1970. Emakeele Selts. Lühiülevaade minevikust ja tänapäevast. [Tallinn]: ENSV Teaduste Akadeemia.

Erelt, Mati 2000. Saateks. - Oma Keel 1, 5-6.

Erelt, Mati 2010. 90 years of the Mother Tongue Society. - Linguistica Uralica 2, 144-153. https://doi.org/doi.org/10.3176/lu.2010.2.05

Hussar, Annika 2010. Emakeele Seltsi väliskeelepäevad. - Keelekosti kodumaalt. Kümme aastat Peterburi keelepäevi. Koost. ja toim. Jüri Valge. Tallinn: Eesti Keele Sihtasutus, 153-159.

Kask, Arnold 1930. Ülevaade Akadeemilise Emakeele Seltsi kümneaastasest tegevusest. - Eesti Keel 4/5, 114-116; 6, 135-143.

Kask, Arnold 1940. Ülevaade AES-i kahekümneaastasest tegevusest. - Eesti Keel 1/2, 34-49.

Kingisepp, Valve 1989. 20 J. V. Veski päeva. - Keelest ja kultuuriloost. Emakeele Seltsi aastaraamat 33. Tallinn: Eesti Raamat, 140-143.

Mei, Killu 2020. Emakeele Seltsi 100. tegevusaasta (2019). - Emakeele Seltsi aastaraamat 65. Peatoim. Mati Erelt. Emakeele Selts. Tallinn: Teaduste Akadeemia Kirjastus, 321-330.

Niilus, V. 1940. Akadeemilise Emakeele Seltsi üldaruanne 20. tegevusaasta (1939.) kohta. - Eesti Keel 1/2, 48-51.

Tender, Tõnu 2000. Emakeele Seltsi keelepäevad - trepp elevandiluust tornist maale. - Emakeele Seltsi aastaraamat 44-45. Peatoim. Mati Erelt. Tartu: Eesti Teaduste Akadeemia Emakeele Selts, 123-134.

Tender, Tõnu, Jüri Viikberg 2020. Tagasivaateks Heino Ahvena 100. sünniaastapäeval. - Emakeele Seltsi aastaraamat 65. Peatoim. Mati Erelt. 
Emakeele Selts. Tallinn: Teaduste Akadeemia Kirjastus, 288-302. http:// dx.doi.org/10.3176/esa65.13

Toimetus 1922. Saatesõna. - Eesti Keel 1, 1-2.

Valge, Jüri 2018. Pool sajandit Johannes Voldemar Veski päevi. - Emakeele Seltsi aastaraamat 63. Peatoim. Mati Erelt. Tallinn: Teaduste Akadeemia Kirjastus, 295-306. http://dx.doi.org/10.3176/esa63.13

Valge, Jüri 2020. Sajand koos Eestiga. Emakeele Selts 1920-2020. Tallinn: Eesti Teaduste Akadeemia Emakeele Selts.

VV 2006 = Eesti kirjakeele normi kehtestamise kord. Vastu võetud 07.09.2006, nr 196. - Riigi Teataja, RT I 2006, 40, 303.

\section{Arhiivimaterjalid}

JProt 329 = RA, ERA.R-2362.2.96. AES-i juhatuse koosolekute protokollid. 10.10.1939-01.12.1949.

JProt 399 = RA, ERA.R-2362.2.162. ENSV TA Emakeele Selts. AES-i juhatuse koosolekute protokollid. 14.12.1949-20.05.1957.

JProt $525=$ RA, ERA.R-2362.2.223. Emakeele Seltsi juhatuse koosolekute protokollid. 30.08.1957-03.03.1962.

JProt 528 = RA, ERA.R-2362.2.223. Emakeele Seltsi juhatuse koosolekute protokollid. 30.08.1957-03.03.1962.

Kiri 567-K = Eesti Omavalitsuse Haridusdirektooriumi kiri nr 567-K 5. veebr. 1942 Tartu Ülikooli Rektorile. - F 2100.19.15. E. W. Tartu ülikooli walitsuse Sekretariaat. Akadeemilise Emakeele Seltsi põhikiri, liikmete nimestikud ja kirjavahetus tegevuse asjus. Algus 15. mail 1920. Lõpp 20. juulil 1942.

Naan, G. 1953. Kiri J. V. Veskile, H. Tobiasele, E. Normannile. 25.09.1953. - RA, ERA.R-2362.1.139. Kirjavahetus organisatsioonilistes ja majanduslikes küsimustes. Seltsi kinnitatud põhikiri. 20.03.1953-04.12.1953.

Order 1944 = Order nr. 7538. Tartu Linna Täitevkomitee Elamute Valitsus. 25.nov. 1944 a. - RA, F 5311.1.24.

Pk-I = Emakeele Seltsi põhikiri. - RA, ERA.R-2362.1.1.

Pk-II = Akadeemilise Emakeele Seltsi põhikiri. Registreeritud Tartu-Võru Rahukogus 29. aprillil 1925. a. nr 1959 all. Tartu: „Postimehe“ trükk, 1925.

Pk-V = Akadeemilise Emakeele Seltsi põhikiri. - RA, ERA.R-2362.1.1.

$\mathbf{P k}-\mathbf{X}=$ Emakeele Seltsi põhikiri. Vastu võetud Eesti Teaduste Akadeemia Emakeele Seltsi üldkoosolekul 30. märtsil 1989.

Pk-XIII = Emakeele Seltsi põhikiri. Heaks kiidetud Emakeele Seltsi üldkoosolekul 24.03.2011 Tallinnas.

Schlossmann, K. 1939a. Kiri Haridusministeeriumi Teaduse ja Kunsti Osakonnale. 6. juunil 1939. - RA, ERA.R-2362.1.83. Materjalid toetuste taotlemise kohta. 16.01.1939-19.12.1939. 
Schlossmann, K. 1939b. Kiri Haridusministeeriumi Teaduse ja Kunsti Osakonnale. 21.III 1939. a. - RA, ERA.R-2362.1.83. Materjalid toetuste taotlemise kohta. 16.01.1939-19.12.1939.

TA 1946 = Akt. Koostatud 31. mail 1946. - F 5311.1.42.

TA 1952 = Kiri nr 9-820, 16.10.1952. - Väljavõtted TA Presiidiumi koosolekute protokollidest ja ENSV Ministrite Nõukogu otsustest Emakeele Seltsi kohta. Alustatud 13. II 1952. Lõpetatud ... . XII 1952. - RA, ERA.R-2362.1.130.

TAP 1959 = Väljavõte Eesti NSV Teaduste Akadeemia Presiidiumi ja Eesti NSV Poliitiliste ja Teadusalaste Teadmiste Levitamise Ühingu Juhatuse Presiidiumi ühise istungi protokollist 4. novembril 1959. a. - ENSV TA Presiidiumi otsuste ning TA presidendi käskkirjade ärakirjad ja nende juurde kuuluvad materjalid. Ministrite Nõukogu määrused. Alustatud 23. jaan. 1959. Lõpetatud 16. nov. 1959. - RA, ERA.R-2362.1.167.

Veski, J. V. 1953 = Kiri Gustav Naanile. 14.10.1953. - RA, ERA.R-2362. Kirjavahetus organisatsioonilistes ja majanduslikes küsimustes. Seltsi kinnitatud põhikiri. 20.03.1953-04.12.1953. 


\title{
100 years of the Mother Tongue Society: the path and landmarks
}

\author{
JÜRI VALGE
}

The article gives an overview of the development and activity of the Mother Tongue Society from its founding on March 23, 1920 to the present day. The formation of the society's name is described, along with its relations with the University of Tartu and the academy of sciences. Also examined are the society's membership and the changes to the society charter that have affected the formation thereof. The Society's notoriety and influence are analysed, the goals set in the charter 100 years ago are compared with the goals of today, and the accomplishments of the Society in relation to those goals are summarized, covering the Society's primary spheres of activity: dialect collection, language development, Estonianization of names, language image building and language planning.

Keywords: Mother Tongue Society, Estonian language

Jüri Valge

Emakeele Selts

Roosikrantsi 6

10119 Tallinn

juri.valge@ut.ee 